\title{
Delinquent and Risk Behaviour among High School Students in a Canadian Prairie City: A Multivariate Analysis
}

\section{Kanada Prairie Şehrindeki Lise Öğrencileri Arasında Suçlu ve Riskli Davranış: Çok Değişkenli Bir Analiz}

\section{Henry P. H. CHOW ${ }^{1}$ (1)}

${ }^{1}$ University of Regina, Department of Sociology and Social Studies, Saskatchewan, Canada

ORCID: H.C. 0000-0001-8875-4998

\section{ABSTRACT}

Drawing primarily on the concepts of self-control, differential association, and social bond, this paper explores delinquent and risk behaviour among high school students in a Canadian prairie city. A total of 262 students attending 14 high schools participated in a self-administered questionnaire survey. The results demonstrated that a notable number of students engaged in various risk (e.g., drinking, unprotected sex, and smoking) and delinquent (e.g., use of illegal substance, theft, and vandalism) behaviour. Multiple ordinary least-squares regression analysis revealed that males, older students, and those who had parents with a lower level of education, considered religion to be less important, scored lower on the self-control scale, indicated having more close friends who used illegal drugs, and reported having been a victim of violent or property crime were shown to have a greater likelihood of risk behaviour involvement. On the other hand, male respondents and those who scored lower on the self-control scale, associated with individuals who used illegal drugs, and reported having been a victim of violent or property crime were found to be significantly more likely to engage in delinquent behaviour. Policy implications of these results for institutional interventions are briefly discussed.

Keywords: Risk and delinquent behaviour, high school students, Canadian prairie city 


\section{EXTENDED ABSTRACT}

Drawing primarily on the concepts of self-control, differential association, and social bond, this paper explores delinquent and risk behaviour among high school students in a Canadian prairie city.

Data for this research were collected as part of a larger survey that was undertaken to explore adolescents' criminal victimization, risk and delinquent behaviour, and attitudes toward the police among high school students in Regina, Saskatchewan. Using a snowball sampling method, a total of 262 students attending 14 high schools participated in a self-administered questionnaire survey. All procedures were adhered to standards set forth by the Research Ethics Board of the University of Regina. Each participant was provided with a copy of an introductory letter outlining the objectives of the study and how the information gathered would be used. It also emphasized that participation was voluntary and that all information obtained would remain confidential and anonymous.

The results demonstrated that a notable number of students engaged in various risk and delinquent behaviour. Specifically, an overwhelming majority of the respondents $(\mathrm{n}=222,84.7 \%)$ reported having consumed alcohol. Three in ten $(\mathrm{n}=78,29.8 \%)$ indicated that they had engaged in unprotected sex and about a quarter reported having gambled $(n=63,24.0 \%)$ or smoked $(n=67,25.7 \%)$. Only a relatively small number of respondents had purchased a lottery ticket $(n=44,16.7 \%)$ or taken part in a physical fight ( $\mathrm{n}=44,16.8 \%)$. Concerning delinquent behaviour, two-fifths of the respondents $(\mathrm{n}=110,41.8 \%)$ indicated that they had used marijuana $(\mathrm{n}=110,41.8 \%)$. Nearly one in three admitted to having vandalized (i.e., having banged up or damaged something on purpose that did not belong to them) $(n=80,30.8 \%)$. About a quarter indicated that they had committed a theft (i.e., having taken things worth $\$ 50$ or less that did not belong to them) $(n=73,28.1 \%)$ or operated a vehicle while under the influence of alcohol $(\mathrm{n}=61,23.3 \%)$ or drugs $(\mathrm{n}=54,20.6 \%)$. Approximately one-fifth reported having taken a car for a ride without the owner's permission $(n=59,22.5 \%)$ or beaten up another person or hurt another person on purpose $(n=51,19.5 \%)$. Relatively few respondents have committed breaking and entering (i.e., having broken into a locked building other than their homes) $(\mathrm{n}=34,13.0 \%)$, sold drugs $(\mathrm{n}=26,10.0 \%)$, carried a weapon on school property $(n=25,9.6 \%)$, or taken part in a gang fight $(n=19,7.3 \%)$.

Multiple ordinary least-squares regression analysis revealed that males, older students, and those who had parents with a lower level of education, considered religion 
to be less important, scored lower on the self-control scale, indicated having more close friends who used illegal drugs, and reported having been a victim of violent or property crime were shown to have a greater likelihood of risk behaviour involvement. On the other hand, male respondents and those who scored lower on the self-control scale, associated with individuals who used illegal drugs, and reported having been a victim of violent or property crime were found to be more likely to engage in delinquent behaviour.

Using a multivariate approach, this study explores the prevalence of adolescent risk and delinquent behaviour in a sample of high school students. It fills a lacuna in the literature on youth problem behaviour in Canada, and provides important insight into the major determinants of adolescents' risk and delinquent involvement. The findings have significant policy and practical implications for individuals (e.g., school administrators, teachers, counsellors, social workers, and law enforcement officers) and agencies (e.g., boards of education, educational institutions, community organizations, governmental agencies) working with young people in various capacities. The results may be used to develop prevention and intervention strategies for delinquent and related behaviour. Given the strong link between delinquent peer association and likelihood of delinquent activity involvement, it is essential to develop pertinent policies and procedures to effectively screen and monitor adolescents for close ties with peers who engage in unlawful and analogous behaviour. The substantial impact of self-control on both risk and delinquent behaviour underscores the importance of strengthening adolescents' self-regulation skills. In view of the close connection between criminal victimization experiences and likelihood of problem behaviour engagement, criminal justice agencies must make a concerted effort to reduce the criminal victimization risks among young people. As well, since criminal victimizations may have serious emotional, physical, psychological, and financial consequences, victim service organizations and schools should provide practical help and support to youth crime victims and to assist them in their recovery.

The findings of the present investigation should be considered in light of several methodological limitations. As this study reports data based on a non-random sample of high school students in a Canadian prairie city, caution must be exercised in interpreting the results. The reliance on cross-sectional data precludes interpretation of causality. Although respondents were assured complete confidentiality and anonymity, bias stemming from self-report and social desirability might have influenced the results. 
Further exploration of variation across types of both institutions (e.g., private vs. public and religious vs. non-religious schools), students (e.g., majority vs. racial, ethnic, and minority groups), and geographic locations (e.g., rural vs. urban) would be informative. The use of a longitudinal design to ascertain the causality of the study variables would also be warranted. 


\section{Introduction}

The issue of youth crime is a major concern for many communities across Canada. Statistics Canada (2016) revealed that Canadian youth aged 12 to 17 were more than twice as likely to be accused of a police-reported crime in 2014 than people aged 25 years and older. While youth aged 12 to 17 made up 7\% of the Canadian population, they accounted for $13 \%$ of individuals accused of crime by police.

Doubtlessly, it is critically important to prevent adolescent risk (i.e., potentially harmful or dangerous) and delinquent (i.e., law-violating) behaviour. Adolescent risk behaviour may set the trajectory for a wide array of future negative outcomes. More specifically, the onset of multiple risk behaviour such as smoking, drinking, and unprotected sex are related to increased risk of lower level of educational attainment, depression, selfharm, future morbidity, and premature mortality (Huang et al., 2012; Kipping et al., 2012). Research has also linked anti-social behaviour, illicit drug and alcohol use, and smoking to suicide risk among adolescents (Bearman \& Moody 2004; Brent 1995; Evans et al., 2001; Hallfors et al., 2004; Heerde et al., 2015; Kokkevi et al., 2011).

As well, there is an increased risk of adult criminality and tendency of negative personal outcomes for delinquent adolescents (Moffitt et al., 2002; Jolliffe et al., 2017). Studies have shown that engagement in delinquent behaviour such as drug dealing, physical fighting, gang involvement was linked to poor academic performance (Hirschfield \& Gasper, 2011; Li \& Lerner, 2011; Maguin \& Loeber, 1996; Metzger et al., 2009) and negative outcomes later in adulthood, especially in terms of occupational attainment (Carter, 2019; Colman et al., 2009; Gilman, et al., 2014; Lanctôt et al., 2007; Tomlinson $\&$ Walker, 2010) and would result in further criminal offending (Dornbusch et al., 2001; Haynie, 2001; Loeber \& Farrington, 2000; Patterson et al., 1989; Simons et al., 2002). There is also compelling evidence that delinquents who went through criminal processing would be more likely to re-offend (i.e., most juvenile offenders become young adult offenders) (Benda et al., 2001; Lussier et al., 2015).

\section{Theoretical Framework}

Engagement in risk and delinquent behaviour is determined by a myriad of personal, family, and societal factors. Understanding these two types of problem behaviour requires the use of an integrated framework. The theories of self-control (also known as the general theory of crime), differential association (i.e., association with delinquent peers), and social bond (i.e., meaningful attachment and participation in convention 
activities), which are among the most influential and empirically tested theoretical perspectives for the explanation of youth risk and delinquent behaviour (McCuddy, 2021; Meldrum et al., 2009; Peterson et al., 2016; Vera \& Moon, 2013), are particularly useful. These theories point primarily to the vitality of familial (i.e., parents) and nonfamilial (i.e., peers) relationships in the prohibition or development of problem behaviour. Early interventions to enhance parenting skills for more effective socialization of young children, to help children develop self-control, and to reduce adolescents' exposure to negative social influences (e.g., delinquent peer groups) are implied in these theories. Notably, there is compelling empirical evidence demonstrating that the implementation of early family or parent training programs aimed at improving socialization and child-rearing practices provide significant benefits for improving self-control and reducing anti-social and delinquent behaviour (Piquero et al., 2016, 2009) and that positive social influences increase self-control and reduce the likelihood of delinquency (Huijsmans et al., 2021; Walter, 2018).

According to the self-control theory proposed by Gottfredson and Hirschi (1990), low self-control is the main source of criminal behaviour and behaviour analogous to crime, and parental socialization significantly influences the development of self-control. Individuals with low self-control tend not only be impulsive, but also insensitive, physical (as opposed to mental), risk-taking, short-sighted, and non-verbal. They have a higher propensity to commit crimes and to engage in other risk behaviour. An impressive body of research demonstrates that low self-control is related to variety of deviant and criminal behaviour (Cheung \& Cheung, 2008; Cretacci, 2008; de Ridder et al., 2012; Hagger et al., 2010; Jiang et al., 2020; Hope et al., 2003; Meldrum et al., 2015; McGloin et al., 2004; Moffitt et al., 2011; Pratt \& Cullen, 2000; Wills et al., 2006).

The basic postulate of the social bond theory is that attachment (i.e., affective ties to significant others such as family members and peers), commitment (i.e., investment in conventional activities such as the pursuit of educational goals), involvement (i.e., time and energy devoted to participation in conventional activities such as school or religious events), and belief (i.e., adherence to societal values and rules) are four vital elements that will prevent individuals from engaging in crime (Hirschi, 1969). There is considerable empirical evidence showing support for the social bond theory in explaining the onset and persistence of criminal pathways (Cernkovich \& Giordano, 1992; Chan \& Chiu, 2015; Chapple et al., 2005; Cusick et al., 2012; Felson \& Staff, 2006; Hart \& Mueller, 2013; Peterson et al., 2016; Liu \& Kaplan, 1999; Sabatine et al., 2017). 
The differential association theory, which was first proposed by Sutherland (1947) as a social theory, contends that deviant behavior is learned through interaction with others in intimate personal groups. Motives, drives, rationalization, and attitudes are formed through social and cultural transmission. Individuals will break the law when they develop more law-breaking than law-abiding attitudes. As pointed out by Kaplan, Johnson, \& Bailey (1987), social relationships with delinquent peers would facilitate involvement in problem behaviour and serve as a vital source of gratification by offering adolescents both personal and interpersonal rewards for engaging in delinquent behaviour. In fact, empirical studies have identified association with delinquent peers to be a consistent predictor of delinquent behavior (Evans et al., 2016; Fletcher et al., 1995; Holt et al., 2012; Pratt, et al., 2009; Thornberry et al., 1994; Warr \& Stafford, 1991).

Drawing primarily on the concepts of self-control, differential association, and social bond, this paper explores delinquent and risk behaviour using a sample of high school students in Regina, Saskatchewan. This study was imperative as the province of Saskatchewan reported the highest police-reported crime severity index (i.e., the crime rate taking into account both the volume and the seriousness of offences) in the nation and the City of Regina was among the top 10 Canadian cities with the highest youth crime rate in 2019 (Moreau et al., 2020).

\section{Methodology}

\subsection{Sample}

Data for this research were collected as part of a larger survey that was undertaken to explore adolescents' criminal victimization, risk and delinquent behaviour, and attitudes toward the police among high school students in Regina (see Chow, 2021, 2014, 2011, 2008). Using a snowball sampling method, a total of 262 students attending 14 different high schools participated in a self-administered questionnaire survey. All procedures were adhered to standards set forth by the Research Ethics Board of the University of Regina. Each participant was provided with a copy of an introductory letter outlining the objectives of the study and how the information gathered would be used. It also emphasized that participation was voluntary and that all information obtained would remain confidential and anonymous.

The sample consisted of $102(38.9 \%)$ male and $160(61.1 \%)$ female students. Respondents ranged in age between 14 and 19 , with a mean age of 15.92 years $(S D=1.15)$. Caucasian 
students ( $n=228,87.4 \%)$ made up an overwhelming majority of the sample. Nearly all respondents $(n=258,99.2 \%)$ were Canadian citizens. Over half of the sample ( $n$ $=128,52.5 \%)$ indicated Catholicism as their religious affiliation. With respect to parents' education, nearly three-fifths of the respondents' fathers had received some post-secondary education ( $n=54,21.3 \%$ ) or completed college or university ( $n=97$, $38.2 \%)$. Over two-thirds of their mothers had received some post-secondary education $(n=77,29.5 \%)$ or graduated from college or university $(n=101,38.7 \%)$. Regarding socio-economic status, slightly more than half of the sample $(n=133,51.0 \%)$ indicated that they belonged to a middle-income family.

\subsection{Measures of Key Variables}

Risk behavior was an additive scale based on respondents' frequency of engagement in various risk-taking behaviour on a five-point scale ranging from 1 (0 times) to 5 (10 times or more) in the past twelve months preceding the survey, including (1) lottery ticket purchase; (2) gambling; (3) smoking; (4) drinking; (5) physical fight; and (6) unprotected sex.

Delinquent behaviour was an additive scale assessed on respondents' frequency of participation in various unlawful activities in the past twelve months on a fivepoint scale ( $1=0$ times to $5=10$ times or more), including having (1) taken a car for ride without the owner's permission; (2) banged up or damaged something on purpose that did not belong to you; (3) sold drugs such as marijuana or hashish (4) taken things worth $\$ 50$ or less that did not belong to you; (5) beaten up anyone or hurt anyone on purpose, not counting fights you may have had with a brother or a sister; (6) broken into a locked building, other than your home; (7) taken part in a gang fight; (8) driven a car or other vehicle while under the influence of alcohol; (9) driven a car or other vehicle while under the influence of drugs; (10) used marijuana; and (11) carried a weapon such as a gun, knife, or club on school property.

\subsection{Analytic Strategy}

Descriptive and inferential analyses were conducted using the Statistical Package for the Social Sciences (IBM SPSS Statistics 26). The internal consistency of all scales used was assessed by Cronbach's alpha reliability test. Two multiple ordinary leastsquares (OLS) regression models were constructed to identify the major determinants of respondents' engagement in risk and delinquent behaviour. 


\section{Major Findings}

\subsection{Engagement in Risk and Delinquent Behaviour}

Respondents were asked to report the frequency of engaging in various risk behaviour in the past twelve months. As shown in Table 1, an overwhelming majority of the respondents $(n=222,84.7 \%)$ reported having consumed alcohol. Three in ten ( $n=$ $78,29.8 \%$ ) indicated that they had engaged in unprotected sex and about a quarter reported having gambled $(n=63,24.0 \%)$ or smoked $(n=67,25.7 \%)$. Only a relatively small number of respondents had purchased a lottery ticket $(n=44,16.7 \%)$ or taken part in a physical fight $(n=44,16.8 \%)$.

Table 1. Risk Behaviour

\begin{tabular}{|l|c|c|}
\hline \multirow{2}{*}{} & Yes & No \\
\cline { 2 - 3 } & $\mathbf{n ~ ( \% )}$ & $\mathbf{n}(\mathbf{\%})$ \\
\hline Lottery ticket & $44(16.7)$ & $219(83.3)$ \\
\hline Gambling & $63(24.0)$ & $200(76.0)$ \\
\hline Smoking & $67(25.7)$ & $194(74.3)$ \\
\hline Drinking & $222(84.7)$ & $40(15.3)$ \\
\hline Physical fight & $44(16.8)$ & $218(83.2)$ \\
\hline Unprotected sex & $78(29.8)$ & $184(70.2)$ \\
\hline
\end{tabular}

Concerning delinquent behaviour, respondents' frequency of engaging in different illegal activities during the twelve-month period preceding the survey is displayed in Table 2. Specifically, two-fifths $(n=110,41.8 \%)$ indicated that they had used marijuana $(n=110,41.8 \%)$. Nearly one in three admitted to having vandalized (i.e., having banged up or damaged something on purpose that did not belong to them) ( $n=80$, $30.8 \%$ ). About a quarter indicated that they had committed a theft (i.e., having taken things worth $\$ 50$ or less that did not belong to them) $(n=73,28.1 \%)$ or operated a vehicle while under the influence of alcohol $(n=61,23.3 \%)$ or drugs $(n=54,20.6 \%)$. Approximately one-fifth reported having taken a car for a ride without the owner's permission $(n=59,22.5 \%)$ or beaten up another person or hurt another person on purpose $(n=51,19.5 \%)$. Relatively few respondents have committed breaking and entering (i.e., having broken into a locked building other than their homes) $(n=34$, $13.0 \%)$, sold drugs $(n=26,10.0 \%)$, carried a weapon on school property $(n=25$, $9.6 \%)$, or taken part in a gang fight $(n=19,7.3 \%)$. 
Table 2. Delinquent Behaviour

\begin{tabular}{|c|c|c|c|c|c|c|}
\hline & $\begin{array}{c}0 \\
\text { times } \\
\end{array}$ & $\begin{array}{c}1 \\
\text { time }\end{array}$ & $\begin{array}{c}2-3 \\
\text { times }\end{array}$ & $\begin{array}{c}4-9 \\
\text { times }\end{array}$ & $\begin{array}{l}\geq 10 \\
\text { times }\end{array}$ & \multirow{2}{*}{$\begin{array}{c}\text { M } \\
(\text { SD) }\end{array}$} \\
\hline & $\begin{array}{c}\mathbf{n} \\
(\%)\end{array}$ & $\begin{array}{c}\mathbf{n} \\
(\%)\end{array}$ & $\begin{array}{c}\mathbf{n} \\
(\%)\end{array}$ & $\begin{array}{c}\mathrm{n} \\
(\%)\end{array}$ & $\begin{array}{c}\mathbf{n} \\
(\%)\end{array}$ & \\
\hline $\begin{array}{l}\text { Taken a car for a ride without the owner's } \\
\text { permission }\end{array}$ & $\begin{array}{l}203 \\
(77.5)\end{array}$ & $\begin{array}{c}22 \\
(8.4)\end{array}$ & $\begin{array}{c}26 \\
(9.9)\end{array}$ & $\begin{array}{c}8 \\
8 \\
(3.1)\end{array}$ & $\begin{array}{c}3 \\
(1.1)\end{array}$ & $\begin{array}{l}1.42 \\
(.87)\end{array}$ \\
\hline $\begin{array}{l}\text { Banged up or damaged something on } \\
\text { purpose that did not belong to you }\end{array}$ & $\begin{array}{c}180 \\
(69.2)\end{array}$ & $\begin{array}{c}39 \\
(15.0)\end{array}$ & $\begin{array}{c}23 \\
(8.8)\end{array}$ & $\begin{array}{c}7 \\
(2.7)\end{array}$ & $\begin{array}{c}11 \\
(4.2)\end{array}$ & $\begin{array}{c}1.58 \\
(1.05)\end{array}$ \\
\hline Sold drugs (such as marijuana or hashish) & $\begin{array}{c}235 \\
(90.0) \\
\end{array}$ & $\begin{array}{c}7 \\
(2.7) \\
\end{array}$ & $\begin{array}{c}8 \\
(3.1) \\
\end{array}$ & $\begin{array}{c}5 \\
(1.9) \\
\end{array}$ & $\begin{array}{c}6 \\
(2.3) \\
\end{array}$ & $\begin{array}{l}1.24 \\
(.80)\end{array}$ \\
\hline $\begin{array}{l}\text { Taken things worth } \$ 50 \text { or less that did } \\
\text { not belong to you }\end{array}$ & $\begin{array}{c}187 \\
(71.9)\end{array}$ & $\begin{array}{c}23 \\
(8.8)\end{array}$ & $\begin{array}{c}21 \\
(8.1)\end{array}$ & $\begin{array}{c}7 \\
(2.7)\end{array}$ & $\begin{array}{c}22 \\
(8.5)\end{array}$ & $\begin{array}{c}1.67 \\
(1.25)\end{array}$ \\
\hline $\begin{array}{l}\text { Beat up anyone or hurt anyone on pur- } \\
\text { pose, not counting fights you may have } \\
\text { had with a brother or a sister }\end{array}$ & $\begin{array}{c}210 \\
(80.5)\end{array}$ & $\begin{array}{c}19 \\
(7.3)\end{array}$ & $\begin{array}{c}18 \\
(6.9)\end{array}$ & $\begin{array}{c}5 \\
(1.9)\end{array}$ & $\begin{array}{c}9 \\
(3.4)\end{array}$ & $\begin{array}{l}1.41 \\
(.95)\end{array}$ \\
\hline $\begin{array}{l}\text { Broken into a locked building, other than } \\
\text { your home }\end{array}$ & $\begin{array}{c}228 \\
(87.0)\end{array}$ & $\begin{array}{c}13 \\
(5.0)\end{array}$ & $\begin{array}{c}14 \\
(5.3)\end{array}$ & $\begin{array}{c}3 \\
(1.1)\end{array}$ & $\begin{array}{c}4 \\
(1.5)\end{array}$ & $\begin{array}{l}1.25 \\
(.74)\end{array}$ \\
\hline Taken part in a gang fight & $\begin{array}{c}242 \\
(92.7)\end{array}$ & $\begin{array}{c}7 \\
(2.7) \\
\end{array}$ & $\begin{array}{c}6 \\
(2.3) \\
\end{array}$ & $\begin{array}{c}2 \\
(.8)\end{array}$ & $\begin{array}{c}4 \\
(1.5) \\
\end{array}$ & $\begin{array}{l}1.16 \\
(.64)\end{array}$ \\
\hline $\begin{array}{l}\text { Driven a car or other vehicle while under } \\
\text { the influence of alcohol }\end{array}$ & $\begin{array}{c}201 \\
(76.7) \\
\end{array}$ & $\begin{array}{c}37 \\
(14.1) \\
\end{array}$ & $\begin{array}{c}12 \\
(4.6) \\
\end{array}$ & $\begin{array}{c}4 \\
(1.5) \\
\end{array}$ & $\begin{array}{c}8 \\
(3.1) \\
\end{array}$ & $\begin{array}{l}1.40 \\
(.89)\end{array}$ \\
\hline $\begin{array}{l}\text { Driven a car or other vehicle while under } \\
\text { the influence of drugs }\end{array}$ & $\begin{array}{c}208 \\
(79.4) \\
\end{array}$ & $\begin{array}{c}26 \\
(9.9) \\
\end{array}$ & $\begin{array}{c}7 \\
(2.7) \\
\end{array}$ & $\begin{array}{c}3 \\
(1.1) \\
\end{array}$ & $\begin{array}{c}18 \\
(6.9) \\
\end{array}$ & $\begin{array}{c}1.46 \\
(1.09) \\
\end{array}$ \\
\hline $\begin{array}{l}\text { Used marijuana (also known as cannabis, } \\
\text { "Grass", "Pot", "Hashish, "Hash", Hash } \\
\text { oil). }\end{array}$ & $\begin{array}{c}153 \\
(58.2)\end{array}$ & $\begin{array}{c}31 \\
(11.8)\end{array}$ & $\begin{array}{c}16 \\
(6.1)\end{array}$ & $\begin{array}{c}12 \\
(4.6)\end{array}$ & $\begin{array}{c}51 \\
(19.4)\end{array}$ & $\begin{array}{c}2.15 \\
(1.60)\end{array}$ \\
\hline $\begin{array}{l}\text { Carried a weapon such as a gun, knife, or } \\
\text { club on school property }\end{array}$ & $\begin{array}{c}236 \\
(90.4)\end{array}$ & $\begin{array}{c}9 \\
(3.4)\end{array}$ & $\begin{array}{c}7 \\
(2.7) \\
\end{array}$ & $\begin{array}{c}2 \\
(0.8)\end{array}$ & $\begin{array}{c}7 \\
(2.7)\end{array}$ & $\begin{array}{l}1.22 \\
(.77)\end{array}$ \\
\hline
\end{tabular}

\subsection{Multivariate Analysis}

To explore the major determinants of respondents' engagement in risk and delinquent behaviour, two multiple OLS regression models were constructed. The operational definitions of the predictor variables included in the models are presented in the Appendix.

As displayed in Table 3, the overall multiple OLS regression model for engagement in risk behaviour was significant $(F(15,247)=15.227, p<.001)$ and explained $44.8 \%$ of the variance. Sex $(b=.105, p<.05)$, age $(b=.123, p<.05)$, parents' education $(b$ $=-.141, p<.01)$, vitality of religion $(b=-.140, p<.01)$, differential association $(b=$ $.183, p<.001)$, self-control $(b=-.175, p<.01)$, property crime victimization $(b=$ 
$.107, p<.05)$, and violent crime victimization $(b=.235, p<.001)$ were associated with engagement in risk behaviour significantly. More specifically, males, older students, and those who had parents with a lower level of education, considered religion to be less important, scored lower on self-control, reported more close friends who used illegal drugs, and indicated having been a victim of a property or violent crime were found to have a greater likelihood of risk behaviour involvement.

With respect to engagement in delinquent behaviour, the overall multiple OLS regression model was significant $(F(15,247)=13.765, p<.001)$ and explained $42.2 \%$ of the variance. Sex $(b=.143, p<.01)$, differential association $(b=.169, p<.01)$, self-control $(b=-.351, p<.001)$, property crime victimization $(b=.131, p<.01)$, and violent crime victimization $(b=.192, p<.001)$ were found to be significantly related to engagement in unlawful activities. In particular, male students and those who scored lower on the self-control scale, indicated having more close friends who used illegal drugs, and reported having been a victim of a violent or property crime were found to be more likely to engage in delinquent behaviour.

Table 3. Multiple OLS regression models predicting risk and delinquent behaviour

\begin{tabular}{|c|c|c|c|c|}
\hline & \multicolumn{2}{|c|}{ Risk Behaviour } & \multicolumn{2}{|c|}{ Delinquent Behaviour } \\
\hline & b & B & b & B \\
\hline Sex & .291 & $.105 *$ & .726 & $.143 * *$ \\
\hline Age & .341 & $.123 *$ & -.105 & -.021 \\
\hline Religious affiliation & .038 & .014 & -.425 & $-.084+$ \\
\hline Vitality of religion & -.146 & $-.140 * *$ & -.094 & -.049 \\
\hline Socio-economic status & .160 & $.093+$ & -.139 & -.044 \\
\hline Employment status & .073 & .027 & .061 & .012 \\
\hline Parents' education & -.113 & $-.141 * *$ & -.103 & -.070 \\
\hline Attitude toward school & -.055 & -.086 & -.032 & -.027 \\
\hline Academic performance & -.240 & -.074 & .139 & .023 \\
\hline Familial support and relationships & -.015 & -.039 & -.007 & -.010 \\
\hline Participation in conventional activities & -.005 & -.028 & -.017 & -.050 \\
\hline Differential association & .540 & $.183 * * *$ & .913 & $.169 * *$ \\
\hline Self-control & -.015 & $-.175 * *$ & -.056 & $-.351 * * *$ \\
\hline Property crime victimization & .294 & $.107 *$ & .660 & $.131 * *$ \\
\hline Violent crime victimization & .856 & $.235 * * *$ & 1.283 & $.192 * * *$ \\
\hline (Constant) & \multicolumn{2}{|c|}{$3.782 * * *$} & \multicolumn{2}{|c|}{$7.296 * * *$} \\
\hline $\mathrm{F}$ & \multicolumn{2}{|c|}{$(15,247)=15.227 * * *$} & \multicolumn{2}{|c|}{$(15,247)=13.765 * * *$} \\
\hline $\mathrm{R}^{2}$ & \multicolumn{2}{|c|}{.479} & \multicolumn{2}{|c|}{.455} \\
\hline Adjusted $\mathrm{R}^{2}$ & \multicolumn{2}{|c|}{.448} & \multicolumn{2}{|c|}{.422} \\
\hline $\mathrm{N}$ & \multicolumn{2}{|c|}{262} & \multicolumn{2}{|c|}{262} \\
\hline
\end{tabular}

$+p<.10 ; * p<.05 ; * * p<.01 ; * * * p<.001$ 


\section{Discussion}

Using data collected from a survey of high school students in a Canadian prairie city, this paper explores the respondents' engagement in various risk and delinquent behaviour. The investigation incorporated a broad range of explanatory variables to account for their behaviour, including violent and property crime victimization experiences, attitudes toward school, academic performance, familial support and relationships, self-control, participation in conventional activities, and differential association. The results have revealed that respondents engaged in a wide range of risk and delinquent behaviour and that a number of socio-demographic and contextual variables were shown to be related to respondents' different levels of risk and delinquent involvement.

Among the various socio-demographic variables, age emerged to be a significant predictor of risk behaviour in this analysis. Younger respondents were revealed to be associated with an increased likelihood of engaging in such behaviour. Indeed, age has long been regarded as a strong correlate of risk and delinquent behaviour. Following the age-crime curve, the prevalence of offending increases during early adolescence, peaks in middle adolescence, and declines steadily thereafter (Duell et al., 2018; McCord et al., 2001).

Sex was found to be a significant predictor of both risk and delinquent behaviour. This is unsurprising as sex has been regarded as the strongest predictor of criminal behaviour, with males exhibiting both a higher prevalence and frequency of offending than females (Broidy et al., 2003; Liljeberg et al., 2010; Gutierrez \& Shoemaker, 2008; KempfLeonard et al., 2001; Rebellon et al., 2016; Moffitt \& Caspi, 2001; Moore \& Hagedorn 2001; Steffensmeier \& Schwartz, 2009; Titzmann et al., 2014). Notably, Gottfredson and Hirschi (1990) have even asserted that sex differences appeared to be invariant across time and space.

Furthermore, vitality of religion was found to be reciprocally associated with risk behaviour. Adolescents who considered religion to be important in their lives were less likely to engage in risk behaviour. This finding is congruent with earlier studies which have demonstrated that religious participation and perceived importance of religion were significantly related to a reduced likelihood of delinquent behaviour engagement and illicit drug use (Bartkowski et al., 2008; Benda \& Corwyn, 1997; Jang et al., 2008; Kelly et al., 2015; Miller, \& Vuolo, 2018; Regnerus \& Elder, 2003; Smith, 2003). 
Regarding parents' education, respondents whose parents had higher levels of education were shown to be less likely to engage in risk behaviour. This may be attributed to better parenting practices as studies have revealed the strong relationship between parents' educational attainment and their knowledge, values, beliefs, and goals about childrearing and child development (Dubow et al., 2009; Morawska et al., 2009; Waylen \& Stewart-Brown 2010). In fact, a substantial body of research has ascertained the strong association between effective parenting practices (e.g., parental supervision and recognition of deviant behaviour) and anti-social and problem behavior in children and adolescents (Hoeve et al., 2009; Sentse et al., 2009).

In addition to the socio-demographic variables, criminal victimization emerged as a significant contributing factor. Both property and violent crime victimization experiences were found to be predictive of risk and delinquent behaviour (Cooley et al., 2015; Cullen et al., 2008; Elrod \& Soderstrom, 2008; Hong et al., 2017; Jackson et al., 2013; Vogel \& Keith, 2015; Ousey et al., 2015; Schreck et al., 2017; Turanovic \& Pratt, 2013; Wong \& Schonlau, 2013; Zeman \& Bressan, 2008). Previous studies have linked direct and indirect criminal victimization to a variety of negative psychological and physical outcomes, such as ailing mental health, substance use, decreased academic performance, and lower expectations for future success (Hinton et al., 2020; Pinchevsky et al., 2014). Indeed, victims' delinquent behaviour may be related to their attempt to prevent further harm, to seek revenge against individuals who they believe are accountable for the harm, or to alleviate their negative feelings (Agnew, 2002).

Consonant with the self-control theory, this research corroborates findings from earlier studies that adolescents who scored lower on the self-control scale were significantly associated with higher levels of involvement in risk and law-violating behaviour (Chan \& Chui, 2015; Hay, 2001; Leas \& Mellor, 2000). It is noteworthy that Pratt and Cullen's (2000) meta-analysis of the research literature on self-control and crime has demonstrated the vitality of self-control regardless of how this concept was measured (i.e., attitudinal vs. behavioural measures), what type of sample was used (e.g., community vs. offender populations and racially homogeneous vs. racially integrated groups), how the study was designed (i.e., longitudinal vs cross-sectional), what variables were included (i.e., whether variables from other competing theories were used), or how the outcome variable (i.e., crime or other forms of analogous behaviour) was conceptualized.

Finally, this analysis lends credence to the vitality of differential association on both risk and delinquent behaviour. This finding, which has been well-documented in the 
literature (Bowman et al., 2007; Kim \& Goto, 2000; Lipsey \& Derzon, 1998; Liu \& Liu, 2016; Matsueda \& Anderson, 1998), underscores the negative impacts of having direct and indirect interaction with individuals who engage in unlawful activities.

\section{Conclusion}

Using a multivariate approach, this study explores the prevalence of adolescent risk and delinquent behaviour in a sample of high school students. It fills a lacuna in the present literature on youth problem behaviour in Canada, and provides important insight into the major determinants of adolescents' risk and delinquent involvement in Regina.

The findings have significant policy and practical implications for individuals (e.g., school administrators, teachers, counsellors, social workers, and law enforcement officers) and agencies (e.g., boards of education, educational institutions, community organizations, and govermental agencies) working with young people in various capacities. The results may be used to develop prevention and intervention strategies for delinquent and related behaviour. Given the strong link between delinquent peer association and likelihood of delinquent activity involvement, it is essential to develop pertinent policies and procedures to effectively screen and monitor adolescents for close ties with peers who engage in unlawful and analogous behaviour. The substantial impact of self-control on both risk and delinquent behaviour underscores the importance of strengthening adolescents' selfregulation skills. In view of the close connection between criminal victimization experiences and likelihood of problem behaviour engagement, criminal justice agencies must make a concerted effort to reduce the criminal victimization risks among young people. As well, since criminal victimizations may have serious emotional, physical, psychological, and financial consequences, victim service organizations and schools should provide practical help and support to youth crime victims and to assist them in their recovery.

The results of the present investigation should be considered in light of several methodological limitations. As this study reports data based on a non-random sample of high school students in a Canadian prairie city, caution must be exercised in interpreting the findings. The reliance on cross-sectional data precludes interpretation of causality. Although respondents were assured complete confidentiality and anonymity, bias stemming from self-report and social desirability might have influenced the results. Further exploration of variation across types of both institutions (e.g., private vs. public and religious vs. non-religious schools), students (e.g., majority vs. racial, ethnic, and minority groups), and geographic locations (e.g., rural vs. urban) would be informative. The use of a longitudinal design to ascertain the causality of the study variables would also be warranted. 
Peer-review: Externally peer-reviewed.

Conflict of Interest: The author has no conflict of interest to declare.

Grant Support: This research was funded by the Social Sciences and Humanities Research Council of Canada and the President's Office of the University of Regina.

\section{References}

Agnew, R. (2002). Experienced, vicarious, and anticipated strain: An exploratory study on physical victimization and delinquency. Justice Quarterly, 19, 603-632.

Bartkowski, J.P., Xiaohe, X., \& Levin, M.L. (2008). Religion and child development: Evidence from the early childhood longitudinal study. Social Science Research, 37, 18-36.

Bearman, P.S., \& Moody, J. (2004). Suicide and friendships among American adolescents. American Journal of Public Health, 94(1), 89-95.

Benda, B.B., \& Corwyn, R.F. (1997). Religion and delinquency: The relationship after considering family and peer influences. Journal for the Scientific Study of Religion, 36(1), 81-92.

Benda, B.B., Corwyn, R.F., \& Toombs, N.J. (2001). Recidivism among adolescent serious offenders: Prediction of entry into the correctional system for adults. Criminal Justice and Behavior, 28(5), 588-613.

Bowman, M.A., Prelow, H.M., \& Weaver, S.R. (2007). Parenting behaviors, association with deviant peers, and delinquency in African American adolescents: A mediated-moderation model. Journal of Youth and Adolescence, 36, 517-527.

Brent, D.A. (1995). Risk factors for adolescent suicide and suicidal behavior: Mental and substance abuse disorders, family environmental factors, and life stress. Suicide and Life-Threatening Behavior, 25, 52-63.

Broidy, L.M., Nagin, D.S., Tremblay, R.E., Bates, J.E., Brame, B., Dodge, K. A., Fergusson, D., Horwood, J.L., Loeber, R., Laird, R., Lynam, D.R., Moffitt, T.E., Pettit, G. S., \& Vitaro, F. (2003). Developmental trajectories of childhood disruptive behaviors and adolescent delinquency: A six-site, cross-national study. Developmental Psychology, 39(2), 222-245.

Carter, A. (2019). The consequences of adolescent delinquent behavior for adult employment outcomes. Journal of Youth and Adolescence, 48(1), 17-29.

Cernkovich, S.A., \& Giordano, P.C. (1992). School bonding, race, and delinquency. Criminology, 30(2), 261-291.

Chan, H.C.O., \& Chui, W.H. (2015). Social bond and self-reported nonviolent and violent delinquency: A study of traditional low risk, at-risk, and adjudicated male Chinese adolescents. Child Youth Care Forum, 44, 711-730.

Chapple, C.L., Tyler, K.A., \& Bersani, B.E. (2005). Child neglect and adolescent violence: Examining the effects of self-control and peer rejection. Violence and Victims, 20(1), 39-53.

Cheung, N.W.T., \& Cheung, Y.W. (2008). Self-control, social factors, and delinquency: A test of the general theory of crime among adolescents in Hong Kong. Journal of Youth and Adolescence, 37, 412-430.

Chow, H.P.H. (2021, February 8). Predicting youth risk and delinquent behaviour: Findings from a survey of high school students in Regina. Paper presented at Graduate Seminar Series, Department of Sociology and Social Studies, University of Regina.

Chow, H.P.H. (2014, November 19). Youth risk and delinquent behaviour in Regina: Some survey findings. Poster presentation at the 2014 GIS \& Data Expo, Data Library Services, University of Regina.

Chow, H.P.H. (2011). Adolescent attitudes toward the police in a western Canadian city. Policing: An International Journal of Police Strategies and Management, 34(4), 638-653.

Chow, H.P.H. (2008). Risk behaviour, criminal victimization, and perceptions of the police: A survey of high school students in Regina. University of Regina, Regina, Saskatchewan.

Colman, I., Murray, J., Abbott, R.A., Maughan, B., Kuh, D., Croudace, T.J., \& Jones, P.B. (2009). Outcomes of conduct problems in adolescence: 40 year follow-up of national cohort. British Medical Journal, 338(7688), 208-211. 
Cooley, J.L., Fite, P.J., Rubens, S.L., \& Tunno, A.M. (2015). Peer victimization, depressive symptoms, and rulebreaking behavior in adolescence: the moderating role of peer social support. Journal of Psychopathology and Behavioral Assessment, 37(3), 512-522.

Cretacci, M.A. (2008). A general test of self-control theory: Has its importance been exaggerated? International Journal of Offender Therapy and Comparative Criminology, 52, 538-553.

Cullen, F.T., Unnever, J.D., Hartman, J.L., Turner, M.G., \& Agnew, R. (2008). Gender, bullying victimization, and juvenile delinquency: A test of general strain theory. Victims \& Offenders, 3(4), 346-364.

Cusick, G.R., Havlicek, J.R., \& Courtney, M.E. (2012). Risk for arrest: the role of social bonds in protecting foster youth making the transition to adulthood. American Journal of Orthopsychiatry, 82(1), 19-31.

de Ridder, D.T.D., Lensvelt-Mulders, G., Finkenauer, C., Stok, F.M., \& Baumeister, R.F. (2012). Taking stock of self-control: A meta-analysis of how trait self-control relates to a wide range of behaviors. Personality and Social Psychology Review, 16(1), 76-99.

Dornbusch, S.M., Erickson, K.G., Laird, J., \& Wong, C.A. (2001). The relation of family and school attachment to adolescent deviance in diverse groups and communities. Journal of Adolescent Research, 16, 396-422.

Dubow, E.F., Boxer, P., \& Huesmann, L.R. (2009). Long-term effects of parents' education on children's educational and occupational success: Mediation by family interactions, child aggression, and teenage aspirations. Merrill-Palmer Quarterly, 55(3), 224-249.

Duell, N., Steinberg, L., Icenogle, G., Chein, J., Chaudhary, N., Di Giunta, L., Dodge, K. A., Fanti, K.A., Lansford, J.E., Oburu, P., Pastorelli, C., Skinner, A.T., Sorbring, E., Tapanya, S., Uribe Tirado, L.M., Alampay, L.P., Al-Hassan, S.M., Takash, H., Bacchini, D., \& Chang, L. (2018). Age patterns in risk taking across the world. Journal of Youth and Adolescence, 47(5), 1052-1072.

Elrod, P., \& Soderstrom, I.R. (2008). Theoretical predictors of delinquency in and out of school among a sample of rural public school youth. Southern Rural Sociology, 23(2), 131-156.

Evans, S.Z., Simons, L.G., \& Simons, R.L. (2016). Factors that influence trajectories of delinquency throughout adolescence. Journal of Youth and Adolescence, 45(1), 156-171.

Evans, W.P., Ricardo, M.M., Betts, S., \& Silliman, B. (2001). Adolescent suicide risk and peer-related violent behaviors and victimization. Journal of Interpersonal Violence, 16(12), 1330-1349.

Felson, R.B., \& Staff, J. (2006). Explaining the academic performance-delinquency relationship. Criminology, 44(2), 299-320.

Fletcher, A.C., Darling, N.E., Steinberg, L., \& Dornbusch, S. (1995). The company they keep: Relation of adolescents' adjustment and behavior to their friends' perceptions of authoritative parenting in the social network. Developmental Psychology, 31(2), 300-310.

Gilman, A.B., Hill, K.G., \& Hawkins, D.J. (2014). Long-term consequences of adolescent gang membership for adult functioning. American Journal of Public Health, 104(5), 938-945.

Gottfredson, M.R., \& Hirschi, T. (1990). A general theory of crime. Stanford, CA: Stanford University Press.

Gutierrez, F.C., \& Shoemaker, D.J. (2008). Self-reported delinquency of high school students in metro manila: gender and social class. Youth \& Society, 40(1), 55-85.

Hagger, M.S., Wood, C., Stiff, C., \& Chatzisarantis, N.L.D. (2010). Ego depletion and the strength model of self-control: A meta-analysis. Psychological Bulletin, 136, 495-525.

Hallfors, D.D., Waller, M.W., Ford, C.A., Halpern, C.T., Brodish, P.H., \& Iritani, B. (2004). Adolescent depression and suicide risk: association with sex and drug behavior. American Journal of Preventive Medicine, 27(3), 224-231.

Hart, C.O., \& Mueller, C.E. (2013). School delinquency and social bond factors: Exploring gendered differences among a national sample of 10th graders. Psychology in the Schools, 50(2), 116-133.

Hay, C. (2001). Parenting, self-control, and delinquency: A test of self-control theory. Criminology, 39(3), 707-736.

Haynie, D.L. (2001). Delinquent peers revisited: Does network structure matter? American Journal of Sociology, $106,1013-1057$ 
Heerde, J.A., Toumbourou, J.W., Hemphill, S.A., Herrenkohl, T.I., Patton, G.C., \& Catalano, R.F. (2015). Incidence and course of adolescent deliberate self-harm in Victoria, Australia, and Washington State. Journal of Adolescent Health, 57(5), 537-544.

Hinton, M.E., Tillyer, M.S., \& Tillyer, R. (2020). Victimization, offending, and expectations for future success among high-risk youth. Deviant Behavior, 1-15.

Hirschfield, P.J., \& Gasper, J. (2011). The relationship between school engagement and delinquency in late childhood and early adolescence. Journal of Youth and Adolescence, 40, 3-22.

Hirschi, T. (1969). Causes of delinquency. Berkeley: University of California Press.

Hoeve, M., Dubas, J.S., Eichelsheim, V.I., Van der Laan, P.H., Smeenk, W., \& Stams, G.J. (2009). The relationship between parenting and delinquency: A meta-analysis. Journal of Abnormal Child Psychology, 37, 749-775.

Holt, T.J., Bossler, A.M., \& May, D.C. (2012). Low self-control, deviant peer associations, and juvenile cyberdeviance. American Journal of Criminal Justice, 37, 378-395.

Hong, J.S., Kim, D.H., \& Piquero, A.R. (2017). Assessing the links between punitive parenting, peer deviance, social isolation and bullying perpetration and victimization in south Korean adolescents. Child Abuse \& Neglect, 73, 63-70.

Hope, T.L., Grasmick, H.G., \& Pointon, L.J. (2003). The family in Gottfredson and Hirschi's general theory of crime: Structure, parenting, and self-control. Sociological Focus, 36, 291-311.

Huang, D.Y., Lanza, H.I., Murphy, D.A., \& Hser, Y.I. (2012). Parallel development of risk behaviors in adolescence: Potential pathways to co-occurrence. International Journal of Behavioral Development, 36(4), 247-257.

Huijsmans, T., Nivette, A.E., Eisner, M., \& Ribeaud, D. (2021). Social influences, peer delinquency, and low self-control: An examination of time-varying and reciprocal effects on delinquency over adolescence. European Journal of Criminology, 18(2), 192-212.

Jackson, C.L., Hanson, R.F., Amstadter, A.B., Saunders, B.E., \& Kilpatrick, D.G. (2013). The longitudinal relation between peer violent victimization and delinquency: Results from a national representative sample of U.S. adolescents. Journal of Interpersonal Violence, 28(8), 1596-1616.

Jang, S.J., Bader, C., \& Johnson, B. (2008). The cumulative advantage of religiosity in preventing drug use. Journal of Drug Issues, 38, 771-798.

Jiang, X., Chen, X., \& Zhuo, Y. (2020). Self-control, external environment, and delinquency: A test of self-control theory in rural China. International Journal of Offender Therapy and Comparative Criminology, 64(16), 1696-1716.

Jolliffe, D., Farrington, D.P., Piquero, A.R., MacLeod, J.F., \& Van de Weijer, S. (2017). Prevalence of life-coursepersistent, adolescence-limited, and late-onset offenders: A systematic review of prospective longitudinal studies. Aggression and Violent Behavior, 33, 4-14.

Kaplan, H.B., Johnson, R.J., \& Bailey, C.A. (1987). Deviant peers and deviant behavior: Further elaboration of a model. Social Psychological Quarterly, 50, 277-284.

Kelly, P.E., Polanin, J.R., Jang, S.J., \& Johnson, B.R. (2015). Religion, delinquency, and drug use: A metaanalysis. Criminal Justice Review, 40(4), 505-523.

Kempf-Leonard, K., Tracy, P.E., \& Howell, J.C. (2001). Serious, violent, and chronic juvenile offenders: The relationship of delinquency career types to adult criminality. Justice Quarterly, 18(3), 449-478.

Kim, T.E., \& Goto, S.G. (2000). Peer delinquency and parental social support as predictors of Asian American adolescent delinquency. Deviant Behavior, 21, 331-347.

Kipping, R.R., Campbell, R.M., MacArthur, G.J., Gunnell, M., \& Hickman, M. (2012). Multiple risk behaviour in adolescence, Journal of Public Health, 34(S1), i1-i2.

Kokkevi, A., Rotsika, V., Arapaki, A., \& Richardson, C. (2011). Changes in associations between psychosocial factors and suicide attempts by adolescents in Greece from 1984 to 2007, European Journal of Public Health, 21(6), 694-698.

Lanctôt, N., Cernkovich, S.A., \& Giordano, P.C. (2007). Delinquent behavior, official delinquency, and gender: Consequences for adulthood functioning and well-being. Criminology, 45, 131-157. 
Leas, L., \& Mellor, D. (2000). Prediction of delinquency: The role of depression, risk-taking, and parental attachment. Behaviour Change, 17(3), 155-166.

Li, Y., \& Lerner, R.M. (2011). Trajectories of school engagement during adolescence: Implications for grades, depression, delinquency, and substance use. Developmental Psychology, 47, 233-247.

Liljeberg, J.F., Eklund, J.M., Fritz, M.V., \& af Klinteberg, B. (2010). Poor school bonding and delinquency over time: Bidirectional effects and sex differences. Journal of Adolescence, 34(1), 1-9.

Lipsey, M.W., \& Derzon, J.H. (1998). Predictors of violent or serious delinquency in adolescence and early adulthood: A synthesis of longitudinal research. In R. Loeber \& D.P. Farrington (Eds.), Serious and violent juvenile offenders: Risk factors and successful interventions (pp. 86-105). Thousand Oaks, CA: Sage Publications.

Liu, J., \& Liu, S. (2016). Are children of rural migrants more delinquent than their peers? A comparative analysis of delinquent behaviors in the City of Guangzhou, China. Crime, Law and Social Change, 66(5), 465-489.

Liu, X., \& Kaplan, H.B. (1999). Explaining the gender difference in adolescent delinquent behavior: a longitudinal test of mediating mechanisms. Criminology, 37, 195-215.

Loeber, R., \& Farrington, D.P. (2000). Young children who commit crime: Epidemiology, developmental origins, risk factors, early interventions, and policy implications. Development and Psychopathology, 12(4), 737-762.

Lussier, P., McCuish, E., \& Corrado, R.R. (2015). The adolescence-adulthood transition and desistance from crime: Examining the underlying structure of desistance. Journal of Developmental and Life-Course Criminology, 1, 87-117.

Maguin, E., \& Loeber, R. (1996). Academic performance and delinquency. Crime and Justice, 20, 145-264.

Matsueda, R.L., \& Anderson, K. (1998). The dynamics of delinquent peers and delinquent behavior. Criminology, 36(21), 269-299.

McCord, J., Widom, C.S., \& Crowell, N.A. (Eds.) (2001). Juvenile Crime, Juvenile Justice. Panel on Juvenile Crime: Prevention, Treatment, and Control. Washington, DC: National Academies Press.

McCuddy, Timothy. (2021). Peer delinquency among digital natives: The cyber context as a source of peer influence. The Journal of Research in Crime and Delinquency, 58(3), 306-342.

McGloin, J.M., Pratt, T.C., \& Maahs, J. (2004). Rethinking the IQ-delinquency relationship: A longitudinal analysis of multiple theoretical models. Justice Quarterly, 21, 603-631.

Meldrum, R.C., Barnes, J.C. \& Hay, C. (2015). Sleep deprivation, low self-control, and delinquency: A test of the strength model of self-control. Journal of Youth and Adolescence, 44, 465-477.

Meldrum, R.C., Young, J.T.N., \& Weerman, F.M. (2009). Reconsidering the effect of self-control and delinquent peers. The Journal of Research in Crime and Delinquency, 46(3), 353-376.

Metzger, A., Crean, H.F., \& Forbes-Jones, E.L. (2009). Patterns of organized activity participation in urban, early adolescents: Associations with academic achievement, problem behaviors, and perceived adult support. The Journal of Early Adolescence, 29, 426-442.

Miller, T., \& Vuolo, M. (2018). Examining the antiascetic hypothesis through social control theory: Delinquency, religion, and reciprocation across the early life course. Crime and Delinquency, 64(11), 1458-1488.

Moffitt, T.E., Arseneault, L., Belsky, D., Dickson, N., Hancox, R.J., Harrington, H., Houts, R., Poulton, R., Roberts, B.W., Ross, S., Sears, M.R., Thomson, W.M., \& Caspi, A. (2011). A gradient of childhood selfcontrol predicts health, wealth, and public safety. Proceedings of the National Academy of Sciences of the United States of America, 108(7), 2693-2698.

Moffitt, T.E., Caspi, A., Harrington, H., \& Milne, B.J. (2002). Males on the life-course-persistent and adolescencelimited antisocial pathways: Follow-up at age 26 years. Development and Psychopathology, 14(1), 179-207.

Moffitt, T.E., \& Caspi, A. (2001). Childhood predictors differentiate life-course persistent and adolescence-limited antisocial path-ways among males and females. Development and Psychopathology, 13, 355-375.

Moore, J., \& Hagedorn, J., Department of Justice, Office of Juvenile Justice and Delinquency Prevention. (2001). Female gangs: A focus on research (NCJ Publication No. 188159). 
Morawska, A., Winter, L., \& Sanders, M.R. (2009). Parenting knowledge and its role in the prediction of dysfunctional parenting and disruptive child behaviour. Child: Care, Health and Development, 35, 217-226.

Moreau, G., Jaffray, B., \& Armstrong, A. (2020). Police-reported crime statistics in Canada, 2019. Canadian Centre for Justice and Community Safety Statistics, Statistics Canada.

Ousey, G.C., Wilcox, P., \& Schreck, C.J. (2015). Violent victimization, confluence of risks and the nature of criminal behavior: Testing main and interactive effects from Agnew's extension of general strain theory. Journal of Criminal Justice, 43, 164-173.

Patterson, G., DeBaryshe, B., \& Ramsey, E. (1989). A developmental perspectives on antisocial behavior. American Psychologist, 44, 329-335.

Peterson, B.E., Lee, D., Henninger, A.M., \& Cubellis, M.A. (2016). Social bonds, juvenile delinquency, and Korean adolescents. Crime and Delinquency, 62(10), 1337-1363.

Pinchevsky, G.M., Fagan, A.A., \& Wright, E.M. (2014). Victimization experiences and adolescent substance use: Does the type and degree of victimization matter? Journal of Interpersonal Violence, 29, 299-319.

Piquero, A.R., Farrington, D.P., Welsh, B.C., Tremblay, R., \& Jennings, W. (2009). Effects of early family/parent training programs on antisocial behavior and delinquency. Journal of Experimental Criminology, 5(2), $83-120$

Piquero, A.R., Jennings, W.G., Diamond, B., Farrington, D.P., Tremblay, R.E., Welsh, B.C., \& Gonzalez, J.M.R. (2016). A meta-analysis update on the effects of early family/parent training programs on antisocial behavior and delinquency. Journal of Experimental Criminology, 12(2), 229-248.

Pratt, T.C., \& Cullen, F.T. (2000). The empirical status of Gottfredson and Hirschi's general theory of crime: A meta-analysis. Criminology, 38, 931-964.

Pratt, T.C., Cullen, F.T., Sellers, C.S., Winfree, L.T., Madensen, T.D., Daigle, L.E., Fearn, N.E., \& Gau, J.M. (2009). The empirical status of social learning theory: A meta-analysis. Justice Quarterly, 27, 765-802.

Rebellon, C.J., Manasse, M.E., Agnew, R., Van Gundy, K.T, \& Cohn, E.S. (2016). The relationship between gender and delinquency: Assessing the mediating role of anticipated guilt. Journal of Criminal Justice, 44, $77-88$.

Regnerus, M.D., \& Elder, G.H. (2003). Religion and vulnerability among low-risk adolescents. Social Science Research, 32, 633-658.

Sabatine, E., Lippold, M., \& Kainz, K. (2017). The unique and interactive effects of parent and school bonds on adolescent delinquency. Journal of Applied Developmental Psychology, 53, 54-63.

Schreck, C.J., Berg, M.T., Ousey, G.C., Stewart, E.A., \& Miller, J.M. (2017). Does the nature of the victimizationoffending association fluctuate over the life course? An examination of adolescence and early adulthood. Crime and Delinquency, 63(7), 786-813.

Sentse, M., Veenstra, R., Lindenberg, S., Verhulst, F.C., \& Ormel, J. (2009). Buffers and risks in temperament and family for early adolescent psychopathology: Generic, conditional, or domain-specific effects? The TRAILS study. Developmental Psychology, 45, 419-430.

Simons, R.L., Stewart, E., Gordon, L.C., Conger, R.D., \& Elder, G.H. (2002). A test of life-course explanations for stability and change in antisocial behavior from adolescence to young adulthood. Criminology, 40, 401434.

Smith, C. (2003). Theorizing religious effects among American adolescents. Journal for the Scientific Study of Religion, 42, 17-30.

Statistics Canada (2016). Youth crime in Canada, 2014. The Daily, February 17.

Steffensmeier, D., \& Schwartz, J. (2009). Trends in girls' delinquency and the gender gap: Statistical assessment of diverse sources. In M.A. Zahn (Ed.), The delinquent girl, (pp. 50-83). Philadelphia, PA: Temple University Press.

Sutherland, E.H. (1947). Principles of criminology. $4^{\text {th }}$ ed. Philadelphia: Lippincott.

Thornberry, T.P., Lizotte, A.J., Krohn, M.D., Farnworth, M., \& Jang, S.J. (1994). Delinquent pears, beliefs, and delinquent behavior: A longitudinal test of interactional theory. Criminology, 32(1), 47-83. 
Titzmann, P.F., Silbereisen, R.K., \& Mesch, G. (2014). Minor delinquency and immigration: A longitudinal study among male adolescents. Developmental Psychology, 50, 271-282.

Tomlinson, M., \& Walker, R. (2010). Poverty, adolescent well-being and outcomes later in life. Journal of International Development, 22(8), 1162-1182.

Turanovic, J.J., \& Pratt, T.C. (2013). The consequences of maladaptive coping: Integrating general strain and self-control theories to specify a casual pathway between victimization and offending. Journal of Quantitative Criminology, 29, 321-345.

Vera, E.P., \& Moon, B. (2013). An empirical test of low self-control theory. Youth Violence and Juvenile Justice, 11(1), 79-93

Vogel, M., \& Keith, S. (2015). Vicarious peer victimization and adolescent violence: Unpacking the effects of social learning, general strain, and peer group selection. Deviant Behavior, 36, 834-852.

Walters, G.D. (2018). Positive and negative social influences and crime acceleration during the transition from childhood to adolescence: The interplay of risk and protective factors. Criminal Behaviour and Mental Health. 28(5), 414-423.

Warr, M., \& Stafford, M. (1991). The influence of delinquent peers: What they think or what they do? Criminology, 29, 851-866.

Waylen, A., \& Stewart-Brown, S. (2010). Factors influencing parenting in early childhood: A prospective longitudinal study focusing on change. Child: Care, Health and Development, 36, 198-207.

Wills, T.A., Walker, C., Mendoza, D., \& Ainette, M.G. (2006). Behavioral and emotional self-control: Relations to substance use in samples of middle and high school students. Psychology of Addictive Behaviors, 20, 265-278.

Wong, J.S., \& Schonlau, M. (2013). Does bullying victimization predict future delinquency? A propensity score matching approach. Criminal Justice and Behavior, 40(11), 1184-1208.

Zeman, K., \& Bressan, A. (2008). Factors associated with youth delinquency and victimization in Toronto, 2006. Crime and Justice Research Paper Series. Statistics Canada Catalogue no. 85-561-M. No. 14. Ministry of Industry. 


\section{Appendix: Predictable Variables Used in Regression Models}

The same set of predictor variables was used in both multiple OLS regression models, including sex, age, religious affiliation, vitality of religion, socio-economic status, employment status, parents' education, academic performance, self-control, social bond (measured using familial support and relationships, participation in conventional activities, and attitudes toward school), differential association (i.e., close friends' use of illegal drugs), and criminal victimization experiences (property and violent crimes).

Self-control was composite score $(M=75.65, S D=15.89)$ based on respondents' degree of agreement or disagreement with twenty-five items measured using a five-point scale ( 1 = strongly disagree to $5=$ strongly agree), including (a) The things I like to do best are dangerous $(M=2.59, S D=1.16)$; (b) I will try almost anything regardless of the consequences $(M=2.30, S D=1.08)$; (c) I often behave in a reckless (careless) manner $(M=2.26, S D=1.17)$; (d) Excitement and adventure are more important to me than security $(M=2.73, S D=1.08)$; (e)I often take risks without stopping to think about the results $(M=2.63, S D=1.22)$; (f) I can easily lose my temper $(M=2.75, S D=1.29)$; (g) Often when I am angry at people, I feel more like hurting them than explaining to them about why I am angry $(M=2.35, S D=1.31)$; (h) When I have a serious disagreement with someone, it's usually hard for me to talk about it without getting upset $(M=3.00$, $S D=1.29)$; (i) I generally make careful plans $(M=3.25, S D=.97)$; (j) A well thoughtout reason for almost everything I undertake $(M=3.11, S D=.93)$; (k) I am careful in almost everything I do $(M=3.17, S D=1.00)$; (1)I can work for a long period of time without becoming bored $(M=2.85, S D=1.17)$; $(\mathrm{m})$ Sometimes I will take a risk just for the fun of it $(M=3.58, S D=1.04)$; (n) Test myself every now and then by doing something a little risky $(M=3.37, S D=1.03)$; (o) I might do something foolish for the fun of it $(M=3.53, S D=1.04)$; (p) I sometimes find it exciting to do things for which I might get caught $(M=3.10, S D=1.19)$; (q) I sometimes take unnecessary chances $(M$ $=3.11, S D=1.10)$; (r) I finding it exciting to ride in or drive a fast car $(M=3.80, S D=$ 1.13); (s) At times, I am rather careless (sloppy) $(M=3.11, S D=1.12)$; (t) I am the type to be bored one minute and excited about something the next $(M=3.33, S D=1.03)$; $(\mathrm{u})$ I often leave jobs unfinished $(M=2.44, S D=1.15)$; (v) I am often somewhat restless $(M=3.01, S D=1.08)$; (w) I usually say the first things that come into my mind $(M=$ 3.19, $S D=1.10)$; (x) I sometimes do silly things without thinking $(M=3.48, S D=1.08)$; and (y) Many times I act without thinking $(M=3.12, S D=1.17)$. This twenty-five-item scale has a Cronbach's reliability coefficient of .911. 
Differential association was a dichotomous variable based on whether or not respondents had close friends who used illegal drugs $(1=$ yes; $0=$ no $)$.

Participation in conventional activities was a composite score $(M=12.99, S D=0.99)$ based on the total number of hours respondents spent on the following activities each week: (1) school activities $(M=4.56, S D=5.54)$; (2) voluntary work ( $M=1.03, S D$ $=2.83)$; and (3) religious activities $(M=.88, S D=1.90)$; and (4) studying and doing homework $(M=6.04 ; S D=5.45)$.

Familial support and relationships was a composite score $(M=13.56, S D=3.46)$ based on respondents' degree of agreement or disagreement with the following four statements using a five-point scale $(1=$ strongly disagree to $5=$ strongly agree): (1) I am getting along well with my father $(M=3.68, S D=1.22)$; (2) I am getting along well with my mother $(M=4.02, S D=1.03)$; (3) If I need advice on something other than school, I often go to my father for advice $(M=2.49, S D$ $=1.29$ ); and (4) If I need advice on something other than school, I often go to my mother for advice $(M=3.37, S D=1.30)$. This four-item scale has a Cronbach's reliability coefficient of .675 .

Academic performance was based on respondents' self-reported grade point average $(M=4.2, S D=.97)$ on a five-point scale $(1=$ Grade "E" or below $50 \% ; 2=$ Grade $\mathrm{D}$ or $50-59 \% ; 3=$ Grade C or $60-69 \% ; 4=$ Grade B or $70-79 \% ; 5=$ Grade A or $80-100 \%$ ).

Attitudes toward school was a composite score $(M=5.08, S D=2.12)$ based on respondents' degree of agreement ort disagreement with the following statements on a five-point scale ( $1=$ strongly disagree to $5=$ strongly agree): (1) I like school very much $(M=2.66, S D=1.16)$ and (2) School is boring $(M=2.43, S D=1.26)$. The coding for the second item was reversed to create a scale that higher scores reflect more favourable attitudes toward school. This two-item scale was found to be internally consistent, with a Cronbach's reliability coefficient of .703.

Property crime victimization was based on whether or not respondents had been a victim of a property crime (e.g., theft, vandalism) in the past two years prior to the survey $(1=$ yes; $0=$ no $)$.

Violent crime victimization was based on whether or not respondents had been a victim of a violent crime (e.g., physical assault) in the past two years prior to the survey (1 $=$ yes; $0=$ no). 
Vitality of religion was based on the question "How important a role does religion play in your life" $(M=2.67, S D=1.30)$ measured on a five-point scale ranging from $1=$ very unimportant to $5=$ very important.

Regarding socio-demographic variables, sex $(1=$ male; $0=$ female $)$, age $(1=16$ to $19 ; 0=14$ to 15$)$, and religious affiliation $(1=$ Protestant or Catholic; $0=$ other) were dummy coded. $S E S(M=3.37, S D=.79)$ was an ordinal scale ranging from 1 (low income family) to 5 (high-income family). Employment status was measured by number of hours spent on paid employment per week $(M=8.61, S D=11.35)$. Parents'education was a composite score $(M=9.97, S D=1.78)$ based on the educational attainment of respondents' father $(M=4.91, S D=1.13)$ and mother $(M=5.24, S D=1.29)$ using a six-point scale $(1=$ some primary school to $6=$ graduated from college or university). 
